\title{
Skills Development and International Development Agenda Setting: Lessons from an Intervention in Northern Nigeria
}

\section{Masooda Bano}

\begin{abstract}
Skills development remains on the international development agenda but fails to get adequate attention. Based on prolonged fieldwork with a particularly marginalised community of children and young adults in the northern Nigerian state of Kano, this article shows how in contexts of extreme poverty the demand for skills training can supersede that for basic education. Further, by drawing on results of a six-month-long skills-training intervention, the article documents the scope for increased experimentation in the delivery of low-cost community-based skills-training programmes and identifies factors that influence programme completion. It also demonstrates that participation in skills-training programmes can dramatically increase entrepreneurial aspirations among marginalised youth; but that without access to credit most fail to pursue their aspirations. Below certain poverty thresholds, the dire resource constraints make change in aspirations an unreliable predictor of possible improvement in future outcomes.
\end{abstract}

Key words: Skills development; non-formal primary education; marginalised youth; micro-credit; aspirations, northern Nigeria. 


\section{Introduction}

What place skills training should command within international development agendas remains an unsettled debate. Technical and Vocational Education and Training (TVET) remained important to development thinking in the 1950s and 1960s, gaining traction again in the 1980s (EC, 2012; OECD, 2012). However, by the 1990s it had largely lost its appeal to the development community (King and Palmer, 2007; EC, 2012; OECD, 2012). A number of factors contributed towards this end. Large TVET programmes aimed at turning around state-run technical institutes to produce graduates with marketrelevant skills proved both costly and ineffective (Billetoft, 2014). Further, with the push for Education for All, development funding available for education became increasingly committed to primary and secondary education (Palmer, 2014). The EFA goals did not entirely omit TVET, as Goals 3 and 6 retained a focus on building 'life skills'; ${ }^{1}$ this dilution of focus from a more narrow conception of skills needed for improved employment and income opportunities, as was the case under TVET, to a more broad and vague concept of 'life skills'—which covers a whole host of skills needed to live in society as a productive member (UNESCO, 2012)—has, however, led to an overall neglect of skills-development agendas among major development agencies (Rose, 2013; Palmer, 2014).

This article argues that, due to this lack of prioritisation and relative confusion on what skills to invest in (Rose, 2013; Palmer, 2014), there has been inadequate experimentation to provide low-cost skills-training programmes for income generation 
for communities living in extreme poverty. This challenge, as will be discussed in some detail in Section 1, has been further reinforced due to a conceptualisation of TVET mainly from the market perspective, as opposed to focusing on equity concerns (Allias, 2012a and 2012b; McGrath, 2012). While non-formal community-based schooling models $^{2}$ have been widely endorsed by all major donors (USAID, 2012; UNICEF, 2014), in skills development such experimentation remains rare. Running large-scale TVET programmes required improving state-run technical training institutes which were both complicated and costly to reform (EC, 2012). Such programmes were complex, as they needed to put in place better governance frameworks, new degreeaccreditation and qualification frameworks, and quality-assurance systems (Billetoft, 2014). Most importantly, in terms of poverty alleviation such formal technical education programmes made limited contributions (Billetoft, 2014): in most lowincome countries, a large proportion of those caught in the poverty trap have no access to secondary-level education, which is normally a prerequisite for entry to technical colleges and institutes (UNESCO, 2012); further, given that technical institutes provide more specialised skills, they are normally located in major cities where there is adequate teaching manpower. These factors make formal TEVT programmes costly to access for rural populations, as they necessitate relocation to urban areas. This increases the total cost of securing the training. Tailoring TVET programmes to meet the needs of marginalised youth thus requires the adoption of approaches oriented more towards human development, rather than approaches with a narrow focus on economic growth (Allias, 2012a and 2012b; McGrath, 2012).

Therefore, the prospect of moving away from cost-intensive TVET programmes to design less costly and more community-relevant skills-training programmes, as is being 
considered by some development agencies (Billetoft, 2014), is promising. Yet, as this article will demonstrate, the potential available to expand the non-formal skillsdevelopment agenda is underutilised by the development agencies, partly because of their prioritisation of basic education for all over skills development (Rose, 2013; Palmer, 2014); and partly due to the adoption of what McGrath (2012) has described as a narrow 'TVET toolkit' approach to designing skills-development interventions.

In support of these arguments, this article draws on evidence from a community-based skills-development intervention trialled with one of the most marginalised rural communities in the northern Nigerian state of Kano: the Tsangaya (Quranic) school students, most of whom are male. The intervention thus was aimed at male Muslim youth between the ages of 14 and 25, enrolled in selected Tsangaya schools. It raises three specific questions: (1) guided by an emphasis on participatory development, how should development agencies respond if a particularly vulnerable community prioritises skills training over basic education as a way out of poverty?; (2) why has there not been as much experimentation and learning in the provision of low-cost community-based skills-development programmes as we have seen in the area of primary education?; and (3) can training in work skills raise the aspirations of poor communities to engage in entrepreneurial behaviour and promote micro-enterprise culture?

This article discusses these issues, drawing on ethnographic fieldwork and survey data concerning recipients of a six-month-long skills-training intervention in northern Nigeria. Section 1 outlines the theoretical framework. Section 2 presents the context and research method. While highlighting the severe educational challenges faced in northern Nigeria, the section counters the assumption that these communities 
ideologically resist modern education. Section 3 records how donors' prioritisation of primary education over skills development can be inconsistent with the preferences of poor communities. Section 4 outlines the viability of a non-formal skills-training programme in terms of retention, completion, and learning outcomes. Section 5 examines some of the factors that could influence the rate of completion. Section 6 draws on results from a before-and-after survey with youth in the intervention and control group to examine the links between skill training, aspirations, and entrepreneurial activity. It provides evidence that aspirations for entrepreneurial activity dramatically increased among students taking part in the skills-training intervention; yet, only those few who received micro-credit were able to put their skills to actual use and generate income. The resource constraint in some of these communities is so severe that change in aspirations alone cannot enable individuals to initiate a new life course.

The article thus also contributes to the growing debate on possible links between aspirations and development (Ray, 2003; Bernard et al., 2014; Serneels and Dercon, 2014). Unlike the arguments presented by some of these studies and others (Powell, 2012; Ibrahim, 2011), this article shows that in contexts of extreme poverty investment in improving aspirations alone might produce little tangible change in outcomes. Under certain poverty thresholds, the community resources are so constrained that increase in aspirations makes no actual difference to outcomes.

\section{Section 1. The conceptual framework}


In the past decade, skills development has regained attention within development circles, but it remains a relatively neglected area of study within academic research in the field of international development (Allais, 2012a and 2012b). This trend has changed in recent years, with a growth in the number of studies arguing for conceptualising TVET in a broader development framework, rather than looking at it from what some have critiqued as a narrow neoliberal and pro-market lens (Allais, 2012a, 2012b; McGrath, 2010). McGrath (2010, 2012) in particular has made an important contribution to inspiring a more conceptually driven research agenda on TVET by highlighting the limitations of the 'TVET toolkit'. In McGrath's (2012: 625) assessment, this TVET toolkit approach is fundamentally flawed, as it is designed to prioritise the preferences of employers and is more responsive to the needs of the market, instead of considering how improved skills can contribute to the broader wellbeing of individuals in challenging contexts. McGrath and other scholars sharing similar concerns instead argue for approaching TVET from a broader platform of human development, human rights, or capability (Allais, 2012a; McGrath, 2012; Powell, 2012).

Looking at TVET from such a broader development framework will, these scholars argue, make development agencies focus not solely on responding to the needs of employers but also on considering who in reality has access to opportunities for skills development, and what kinds of skill training are needed in communities which might have no access to formal training programmes or the formal employment market.

This article cannot either support or contradict the association that many of these authors make between neoliberal policies and the adoption of a narrow TVET toolkit approach by the donors (Allais, 2012a, 2012b), given that the fieldwork was not 
designed to address that concern. However, whatever the motives or rationales behind donors' preference for this TVET toolkit approach, the evidence from the intervention in Kano discussed in this article does support the need to adopt a more bottom-up approach to skills development if TVET is to be an effective part of poverty-alleviation programmes. This is so because the majority of the poor operate in the informal economy and often need skills that can help them to be self-employed; further, they often lack primary and secondary education, which is required to gain entry into formal TVET programmes.

At the same time, as has been noted by some of these studies arguing for approaching TVET within a capability or broader human-development framework, the evidence presented in this article shows that access to skills training can greatly enhance aspirations for entrepreneurial activity among marginalised youth, even in contexts of extreme economic deprivation. This is in line with the positive association that other scholars have noted between skills-training opportunities and improved aspirations (Ibrahim, 2011; Powell, 2012; Conradie, 2013; Conradie and Robeyns, 2013). Powell (2012), for example, has used the capability approach to argue that skills-development programmes can contribute to well-being by increasing students' 'ability to dream', or their 'capability to aspire'. However, while recording this association between skills training and improved entrepreneurial aspirations, the evidence presented in this article questions whether these heightened aspirations can actually be interpreted as indications of improved well-being.

The study of aspirations, normally a focus of psychology, is gaining increasing currency in development circles. Aspirations are defined as forward-looking goals or targets 
(Locke and Lathan, 2002). Within development studies there is currently much interest in exploring the links between aspirations and poverty, with increasing numbers of studies arguing that lower aspirations lead to lower achievement. Bernard et al. (2014: 3) note that 'In economic terms, we might think of aspirations as bounds among individuals' preferences, the limits of the choice sets which they consider as relevant for them and motivate their actions'. They further argue: 'Once formed, our aspirations can function like other mental models in limiting the possible futures we consider by focusing our attention on some future options and filtering out others' (Bernard et al. 2014: 3).

Drawing on the work of Appadurai (2001), Ray (2003), and Bandura (1997), Bernard et al. (2014) also note that individuals' aspirations are also forcefully shaped by observing what happens to individuals whose behaviours they can observe and with whom they can identify. Aspirations, they argue, motivate behaviour. Recent studies find significant impacts of aspirations on choice and on attainment.

Tempering this optimism associated with increased aspirations to improve well-being, this article highlights the need for caution. The evidence presented here indicates that below certain poverty thresholds aspiration alone might not help to change reality. Further, there is a need to study whether interventions aimed at increasing aspirations can actually reduce individual well-being. In Timepass, Craig Jeffrey (2010) presents an interesting account of university-going Indian youth from the lower- or middleincome classes who, as a result of heightened expectation due to their university education, end up diverting their energies to unproductive endeavours in expectation of formal-sector jobs that are simply unavailable. When launching small-scale development programmes aimed at enhancing aspirations, we need to study whether 
such interventions do indeed lead to improved well-being, or whether they might in the long term end up leaving the participants even more frustrated with their social and economic context.

\section{Section 2. Background, intervention, and method}

Northern Nigeria presents one of the most challenging development contexts: the poverty rates are high, literacy levels are low, and gender-based differentiations in educational and economic outcomes are wide (Antoninis, 2014; UNICEF, 2015). Nigeria today has the largest share of the world's out-of-school children, and the majority of them are in the northern half of the country (GMR and USI, 2014). Within this overall high level of deprivation, there is a particularly vulnerable group which has gained the attention of both national and state governments, as well as international development agencies. This group consists of almajirai (singular, almajiri): male children and young adults ${ }^{3}$ who are enrolled in a Tsangaya (Quranic) school, a centuries-old model of Quranic teaching (Bano, 2008; CUBE, 2008). Tsangaya schools operate as a boarding facility where parents leave their sons with the malamai (Quranic teachers; singular, malam) to study the Quran. In the pre-colonial period, when these schools received patronage from the state as well as societal elites, malamai and the broader community were well placed to provide for the basic needs of these children and young adults (CUBE, 2008).

Today, however, most children in these schools either resort to begging or undertake odd jobs to help complement the malam's income and ensure the provision of daily meals for themselves (CUBE, 2008). These children and young people are thus viewed as being exposed to multiple levels of vulnerability: food insecurity, lack of access to modern education, and possible harassment or abuse when begging on the streets 
(Hoechner, 2011). Further, their number is not insignificant: in Kano, a 2003 census of Islamic and Quranic schools recorded 23,000 schools (CUBE 2008); compared with this large sector, the total number of state primary and secondary schools in 2016 was less than $6,000 .{ }^{4}$ While the number of students in individual Tsangaya schools is normally much smaller compared with those in state schools, when grouped with other categories of Islamic school (Islamiyya and Ilmi) these schools form an important part of the educational landscape in northern Nigeria (CUBE, 2008).

In 2008, as part of a major UKAID bilateral education-sector support programme implemented across six states of Nigeria, a non-formal schooling intervention was developed to provide primary education for children from Tsangaya schools (ESSPIN, 2010). The primary focus of this bilateral aid development programme was on improving education in state schools; but, at the request of the state government of Kano, a non-formal education programme was also designed for children enrolled in Tsangaya schools (MoE, 2008, 2010). The government itself had made a number of attempts to this effect, but with limited success. The government officials attributed the failure of these earlier efforts to an alleged ideological resistance to modern education among malamai. In northern Nigeria, modern schools are associated with colonial rule and Christian missionary work, thereby continuing to have a negative connotation, especially among the religious communities (CUBE, 2008); the Hausa word boko, used to refer to modern schools, to date carries this negative association.

The results were striking: malamai overwhelmingly allowed children to pursue modern education in non-formal schools set up under this programme. Despite popular assumptions to the contrary, other researchers have found similar evidence within this 
population of willingness to pursue modern education (Brigaglia, 2008; Hoechner, 2014). Between 2010 and 2014, Kano state successfully expanded the non-formal primary-education programme from three Local Government Authorities (LGAs) to 16. ${ }^{5}$ The details of this non-formal primary-education programme are available in another study (ESSPIN, 2010); it is briefly introduced here because its success (KERD, 2014) in turn informed the design of the non-formal skills-training programme analysed in this article.

The findings presented in this article draw on close observation of the development of this non-formal primary-education programme as it evolved between 2010 and 2016, as well as the six-month non-formal skills-development intervention, which was introduced with the same student population in 2014. This prolonged qualitative fieldwork helps to illustrate how in certain communities demand for skills training surpasses the demand for basic education. Further, a baseline and post-intervention survey was implemented with a total of 1,042 Tsangaya students who were eligible to take part in the skills-training intervention. This baseline list was developed by approaching the malamai of 30 Tsangaya schools to identify eligible children and young people, who were required to be between the ages of 14 and 25 years. Out of the total of 1,042 students identified, 521 were randomly selected to take part in the skillstraining programme and became the intervention group, while the other half were assigned to the control group. The follow-up survey was carried out four months after the completion of the skills-training intervention. Results from the baseline and postintervention surveys helped to assess the impact of skills training on students' attitudes and entrepreneurial aspirations. I was engaged in the design of both the non-formal 
primary-education programme and the skills-training intervention, and in developing the studies aimed at understanding what works and what does not.

\section{Section 3. Primary education or skills training: whose decision?}

As outlined above, the education-sector support programme under which both these interventions were trialled was mainly focused on primary-education reforms. In 2009, mobilisation work was begun in order to convince the malamai to release the children and young adults enrolled in their Tsangaya schools for two to three hours on five days a week to pursue modern education in a non-formal school that was being established in their vicinity. The programme began in three Local Government Authorities (LGAs): Fagge (urban), Kumbotso (semi-urban), and Albasu (rural). However, from the very beginning, the field mobilisers from across the three Local Government Education Authorities (LGEAs), the implementing agency for the non-formal primary-education intervention, reported that, when offered modern education, malamai were instead asking for skills-training opportunities for their students. During the mobilisation meetings, malamai were informed about the benefits of modern education and its links to formal employment markets. They were also reassured that the flexible learning hours under this non-formal model would allow their students to complement the Islamic education they already received at the Tsangaya school, rather than replace it. Further, prominent religious scholars and traditional elders were brought on board to convince the malamai that Islam's emphasis on pursuing modern knowledge is equal to the emphasis that it places on Islamic knowledge. This mobilisation strategy was based on the perception that the malamai were likely to be ideologically opposed to modern education. The finding across the three LGAs, however, was that the malamai did not 
question any of these assertions; their only concern was that in their view their students needed skills training more than modern education.

As a member of the design team, my engagement with these interventions allowed me to personally attend many of these mobilisation meetings and take part in discussions with the malamai and the students. During the discussions, it became very clear that the malamai did not have a serious ideological resistance to modern education, as Brigaglia (2008) and Hoechner (2014) have also argued; instead their concern was that modern education provided no benefits. Due to the poor quality of state schooling, the links between modern education and employment were perceived to be non-existent. In such a context, skills development was seen as the best route for improving students' future income prospects and well-being. Here it is important to note that the kinds of skill training requested were not technically intense; most would fall into the category of traditional skills: tailoring, carpentry, welding, motor mechanics, etc. (see Table 2). Arguably, training in such traditional skills should be accessible even to youth from such marginalised communities. But, for reasons that will be discussed in Section 4, malamai as well as the students interviewed in the Tsangaya schools noted their inability to access training even in these traditional skills.

Given the persistence of this demand for skills training, once the non-formal primaryeducation programme was fully developed, a non-formal skills-training intervention was designed to complement the primary-education programme. The rationale for designing a non-formal skills-training institute rested on the basic fact that the technical training institutes were mainly located in the urban areas, making them logistically inaccessible to most of the target population. Thus, the core features of a non-formal 
community-school model were absorbed into the skills-training intervention (see Table 1).

Table 1: Non-formal primary-education model adapted to skills training

\begin{tabular}{|c|c|c|}
\hline No. & Non-formal primary-school model & $\begin{array}{l}\text { Non-formal skills-training } \\
\text { model }\end{array}$ \\
\hline 1 & Flexible teaching hours & Flexible training hours \\
\hline 2 & Teacher from within the community & $\begin{array}{l}\text { Trainer from within the } \\
\text { community }\end{array}$ \\
\hline 3 & $\begin{array}{l}\text { School space provided by the } \\
\text { community }\end{array}$ & $\begin{array}{l}\text { Training imparted at a location } \\
\text { provided by the community }\end{array}$ \\
\hline 4 & Malam helps select the teacher & Malam helps select the trainer \\
\hline 5 & $\begin{array}{l}\text { Teachers are paid token allowances, } \\
\text { not proper salaries (Naira } 4,000 \text { per } \\
\text { month in both urban and rural LGAs; } \\
\text { later raised to Naira 7,000). }\end{array}$ & $\begin{array}{l}\text { Trainers are paid small monthly } \\
\text { allowances, but higher than the } \\
\text { rates paid to teachers recruited for } \\
\text { non-formal primary schools, } \\
\text { because otherwise the trainers } \\
\text { were not interested (Naira 15,000 } \\
\text { per month in the urban LGAs; } \\
\text { Naira } 10,000 \text { in the rural LGA). }\end{array}$ \\
\hline
\end{tabular}

In line with the non-formal education model, the trainer had to be from the local community, so that the students could easily walk to his workshop or he could regularly visit a central training site. Further, the malam had to be involved in his selection, so that he had some level of trust in the trainer and could also monitor the training process. 
Also, the trainer had to agree to meet the monthly learning targets (milestones). Such community-based training overcame the logistical challenges; even young adults from rural areas who could not join centralised training programmes, given the finances and time required to get to the technical training institutes, could actively participate.

\section{Section 4. Viability of the non-formal skills-training model}

Assessing the viability of developing a skills-training programme that absorbs core features of a non-formal primary-education programme, as opposed to being run under the 'TVET toolkit' approach analysed in Section 1, requires looking at the student retention and completion rates as well as the learning outcomes. This section presents evidence to this effect.

\section{Retention and completion}

Although the skills-training intervention was launched in response to very high demand for skills training among the Tsangaya school student population and the malamai, this in itself could not guarantee regular attendance and their completion of the six-month training programme, due to the high opportunity costs for the participants. These young almajirai had many competing demands on their time, which could lead to high dropout rates or irregular attendance, as has been noted in other studies looking at decisions made by children exposed to the pressure of child labour (Admassie, 2003). Besides pursuing Quranic education, many of these Tsangaya students had to either beg for food or run small errands for families in the local area in order to secure their daily meals. Some of these students, especially the older youth in the urban LGAs, such as Fagge, also spent considerable time begging at traffic signals on major roads. There was, thus, 
no guarantee that, once the training started, their attendance would be regular. Yet the student-attendance register and the baseline and follow-up surveys designed to monitor progress showed that 78 per cent of the total population in the intervention group reported completing the training. This completion rate was 12 per cent higher than that for the non-formal primary-education programme that was implemented with the same population of Tsangaya students (ESSPIN, 2015).

The results also showed that urban or rural locations can have a bearing on attendance and completion. As Figure 1 illustrates, the completion rate at 83.22 per cent was highest in Fagge, the urban LGA, followed by Kumbotso, the semi-urban LGA, which had a completion rate of 75 per cent. Albasu, the rural LGA, showed a comparatively lower completion rate of 68.32 per cent. Qualitative fieldwork during visits made to the training centres in the three LGAs indicates two factors that potentially explained this variation between urban and rural sites. First, the difference in completion rates was partly reflective of the additional challenges faced in finding good trainers in a rural LGA. Further, it is also indicative of limited exposure to business opportunities among youth in the rural areas, where smallholder farming is the norm. Qualitative fieldwork suggests that this lack of exposure to business activity could lead to slightly lower motivational levels than those demonstrated by youth based in the urban and semiurban LGAs, as there were fewer role models available to inspire them. 
Source: Own survey data

Out of the 22 per cent of students who had dropped out, 15 per cent reported begging as the primary cause of drop-out; 4 per cent attributed it to dissatisfaction with the trainer, while another 6 per cent noted that the training centres were too far away (see Figure 2). These responses were not mutually exclusive. A combination of factors, influenced by survival needs as well as those related to the quality of training, thus influenced the decision to carry on or not. It is important to note here that, since the majority of the students included in the baseline survey were also available during the follow-up survey, the drop-out rate could not be explained by migration out of town, which could have been expected, given that the students of Tsangaya schools do at times undertake seasonal migration, either to help their parents on farms or to earn some income. 


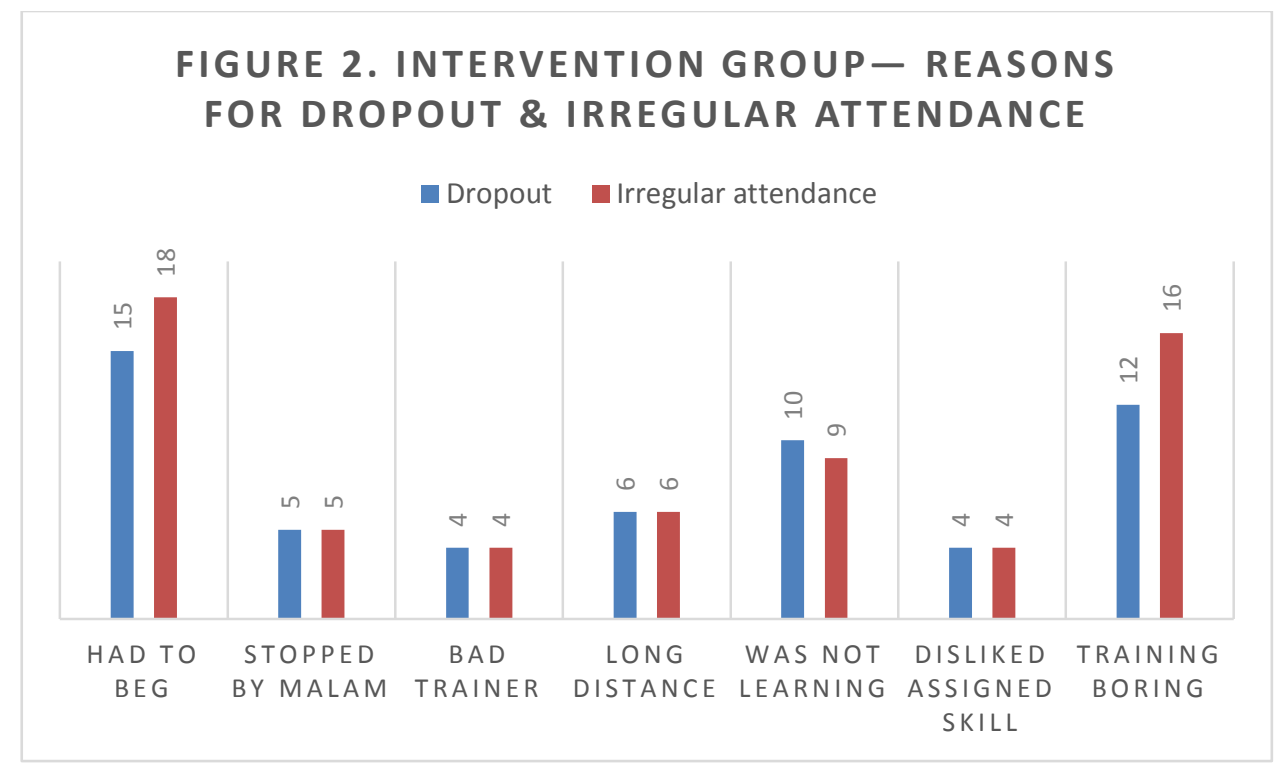

Source: Own survey data

\section{Level of skill acquisition}

To monitor the level of skill acquisition at the start of the six months' training, a clear learning-milestone chart was developed for each selected skill. Actual learning against those milestones was monitored through regular monitoring visits. As expected, the final quality of skill acquisition varied per student, with some showing ability to produce finer products than the average. However, the last round of monitoring visits, made in the final week of the six-month training programme, showed that in all the clusters, the students who had completed the training and were regular in attendance had learned the core skills to produce the basic products on their own. The end of the programme survey also recorded high student confidence in the level of skills learned: 20 per cent of the students ranked themselves as 'excellent' in terms of level of skill acquisition, while another 74 per cent of the students ranked themselves as 'good'. These results do suggest that it is viable to recruit skills trainers from within the community, as has been proven by the non-formal primary-education programmes for the community-based teachers. 
Further, acquisition of these basic income-generating skills might appear to be only a small gain within a development policy agenda concerned with large-scale reforms; but it is important to remind ourselves of how access to these basic skills was reported to be a major challenge by the malamai and the students. The challenges that Tsangaya school students faced when trying to secure such training on their own were two-fold: one, an inability to pay the fee of the trainer and the cost of the training materials; and two, the fact that, even if the students could pay to be attached to the trainer, the trainers did not impart professional training. Young people interviewed reported being asked to run small errands by the trainers, rather than being trained in the required skill. This low level of learning in turn was argued to frustrate the students, leading them to drop out. Malamai and students also mentioned that some trainers see their trainees as future rivals and thus deliberately refrain from imparting knowledge of the given skill.

The finding from this non-formal skills-training programme is that local trainers from within the community could be recruited for a small fee $(10,000-15,000$ naira per trainer per month), and they could be induced to impart training according to the agreed learning milestones. While some NGOs occasionally try non-formal skills- training models (ILO, 2011; Amin et al., 2016), experimentation in this field is still very rare, even though non-formal models in primary education are widely adopted. There is thus a need for more innovation and experimentation in the delivery of non-formal skillsdevelopment programmes if they are to play a role in poverty alleviation.

\section{Section 5. Factors affecting completion}


The preceding sections have tried to establish the high demand for skills development in communities faced with severe livelihood challenges; and they have shared details of a non-formal skills-development model that adapted features of non-formal primaryeducation programmes. This section shares results from probit and logit models aimed at identifying the factors that might have contributed to causing 22 per cent of the students enrolled in the programme to drop out before completing the training. The technical results are presented in the Technical Annex; here the key results are briefly discussed. In the previous section, we have already seen that students identified their survival needs and the quality of training as playing a role in affecting their ability to complete the programme and to ensure regular attendance. The models identify additional factors that could have a bearing on completion rates: the age of the student, the type and level of education secured prior to starting the skill training, basic nutritional levels (assessed through questions asked about security of three daily meals), and attributes of the trainer (see Annex, section 1). The probability of completing training between age ranges on average is positive, implying that one extra year increases the probability of completing training. However, this seems to be a non-linear relationship, implying that the probability change may be more positive in the early years and less positive, if not negative, for later age ranges. It is quite likely that students beyond a certain age encounter higher opportunity costs which limit their ability to invest in the training. Further, the tests show that a child who gets enough to eat is more likely to finish the training programme, compared with one who does not get enough to eat. This result is significant (see Annex, section 1).

As for the trainer, a number of attributes seemed to have a bearing on a child's decision to complete the training (see Annex, section 2). The probit and logit models presented 
in the annex suggest that a bad workshop reduces the probability of completing training by 14 per cent at the 95 per cent confidence interval. Secondly, whether or not the trainer scolded the students during training seemed to have an impact on completion. The positive coefficient and marginal effect implies that scolding actually increased the probability of a child completing the schooling. Interestingly, whether the trainer scolded the young person during the training increased the student's probability of completing the training programme by 20 per cent in the probit model, at the 99 per cent confidence interval. One interpretation of this may be that fear of being scolded by the trainer motivated the young people to complete the training. Further, a trainer who 'shared the skills fully' increased the probability of young people completing the training programme by 24 per cent. Thus, the findings suggest that the attributes of the trainer have an important bearing on programme completion.

\section{Section 6. Aspirations and entrepreneurial activity}

In addition to testing the viability of developing non-formal skills-training programmes along the lines of non-formal primary-education programmes, this skills- training intervention also helped to assess whether participation in the skills training changed the entrepreneurial spirits and aspirations of the participating students, and whether access to micro-credit played any role in it. At the end of the intervention, small loans of varied sizes were disbursed to a small number of randomly selected youth from among those who had successfully completed the training. A critical learning objective of this intervention was to see how the loans would affect the ability of these young adults to start their own business. Loans were meant to be interest-free and of different sizes, to shed light on which loan size might be optimal. Consultations with the trainers showed that many of the skill areas required at least 100,000 naira to get started, 
because of the nature of equipment required, or the need to hire a workshop; however, a few skills could lead to income-generation activities with very small start-up capital. Three different categories of loan were thus disbursed: group loans (large); individual loans (medium); and individual loans (small) (see Table 2).

Table 2: Key skills and loan sizes

\begin{tabular}{|l|l|l|}
\hline Loan Category & Loan Size & Skill Area \\
\hline Group Loan & N100,000 & Embroidery, Welding, Leather \\
& & Work \& Shoe Making, Dyeing, \\
& & Barbering \\
\hline Individual Loans & $\mathrm{N} 25,000$ & Tailoring, Carpentry \& Wood \\
(Medium) & & Carving \\
\hline Individual Loans (Small) & N10,000 & Generator Repair, Electrical Work, \\
& & Motorcycle Repair, Tricycle Repair \\
\hline
\end{tabular}

The post-intervention survey conducted at the end of the six-month training programme showed that, while aspirations can indeed change quickly, the opportunities available to change a young person's future unfortunately do not. The baseline survey results had shown similar skill levels and future aspirations among population in the control and intervention groups: only 15 per cent of the students in the control and intervention groups had reported having prior training in any skill, and a further 100 per cent of students in both the groups had expressed willingness to take part in the skills-training programme. The future career aspirations reported by students in the baseline survey across the two groups were also very similar: close to 30 per cent students in each group wanted to run a business, while becoming a teacher of religious education was the next 
most popular career option. The work skills preferred were also similar across the two groups: around 34 per cent preferred sewing, 25 per cent preferred carpentry, and 22 per cent preferred motor mechanics.

The results from the post-intervention survey showed that 96 per cent of the students in the intervention group said that they would like to start their own business using the skill they had learned, as opposed to only 30 per cent expressing this aspiration during the baseline survey. This showed that their aspirations for entrepreneurial activity had increased threefold. Among students in the control group, however, there was no similar surge in aspirations. Further, 83 per cent of the students in the intervention group said they would like to take an interest-free loan to set up their business, as opposed to only 23 per cent of the students in the control group expressing similar ambitions. Thus, the training had a major impact in terms of increasing the students' aspirations to undertake income-generation activities and to take loans to initiate them.

Yet, when asked what they had been doing since the completion of the training, the two groups showed no difference in their responses: 21 per cent reported looking for a job, 30 per cent reported trying to set up a business, and another 30 per cent reported running small errands. These results were very similar to those recorded by the control group. Such outcomes are understandable if we keep in mind that only 13 per cent of students in the intervention group reported having access to funds or loans that might enable them to actually set up a business or start income-generating activity. Thus, while a comparison of responses from the baseline and final surveys shows increased aspirations and desire to move towards establishing a small business enterprise (see Figure 3), it also shows that it is difficult to pursue these aspirations unless there are 
improved linkages with the employment market, or easy availability of seed capital. As Figure 3 illustrates, the long-term aspirations of the students in the intervention group had indeed changed: 44 per cent of this group reported wanting to run a business of their own in five years' time, compared with only 19.38 per cent in the control group. Further, close to 47 per cent students in the control group wanted to become a Quranic malam, while this aspiration was expressed by only 26 per cent students in the intervention group. But, in terms of what they were actually doing, the intervention group reported no greater increase in entrepreneurial activity than was reported by the control group.

\section{Figure 3: Long-term career aspirations}

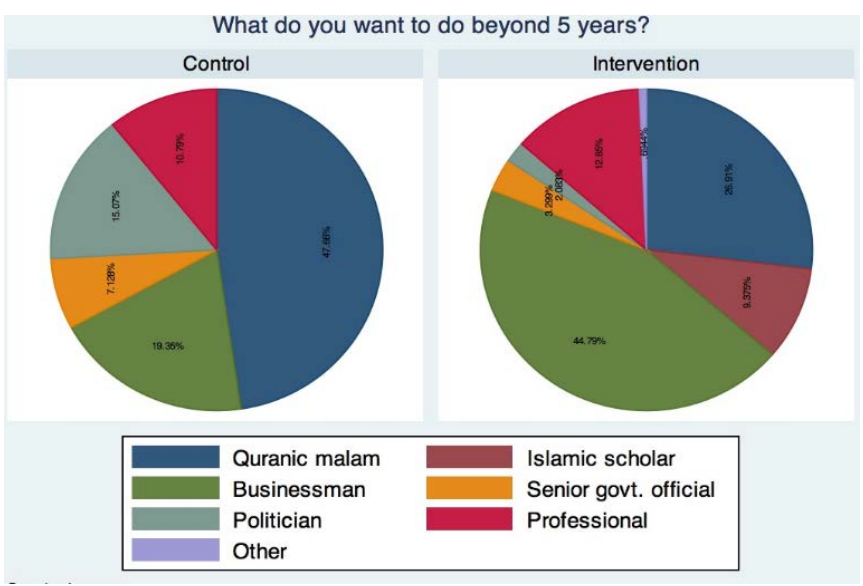

The challenges faced by the students aspiring to set up their own business after acquiring skills are not surprising. It was clear during the field visits that without provision of loans there is a very limited chance that the majority of these students will be able to use their skills to generate an income. Without the supporting infrastructure which facilitates linkages with the employment market, or provisions of loans and business-management training, these students' ability to use their acquired skills to generate income remains restricted. This implies that to bring about meaningful improvement in the students' income-generation potential, non-formal skills- 
development interventions must facilitate access to micro-credit. Further, there is a need to consider whether joint loans that encourage young people to work together to establish a micro-enterprise might be more effective than individual loans. Asked whether they would like to set up a business with someone else or alone, 67 per cent of the respondents said they would like to collaborate with someone else. The reasons given, which were not mutually exclusive, as students were asked to mark all the relevant responses, included: don't have enough skill level (46 per cent); don't have enough funds (34 per cent); don’t know how to manage accounts (28 per cent); don’t have confidence to do it alone (28 per cent); can run a bigger business when working with others (38 per cent).

To rule out the possibility that responses were shaped by differences in student backgrounds, Table 3 documents how the basic profiles of the youth in the control and intervention groups and the income levels of their families were very similar. The father's professional background is comparable for youth in both the groups, with close to 55 per cent of youth in both the groups reporting their fathers as being farmers.

Table 3: Baseline survey-father's profession

\begin{tabular}{llc}
\hline Father's Profession & Control Group & Intervention \\
& Group & \\
\hline Business/trading & $23.57 \%$ & $19.20 \%$ \\
\hline Civil servant & $1.99 \%$ & $1.00 \%$ \\
\hline Farmer & $56.08 \%$ & $54.61 \%$ \\
\hline High-skilled professional & $0.74 \%$ & $1.00 \%$ \\
\hline Religious professional & $1.99 \%$ & $3.99 \%$ \\
\hline Seller & & \\
\hline
\end{tabular}




\begin{tabular}{lcc}
\hline Semi-skilled labour & $7.94 \%$ & $9.98 \%$ \\
\hline Teacher & $4.47 \%$ & $5.99 \%$ \\
\hline Unskilled labour & $3.47 \%$ & $3.74 \%$ \\
\hline
\end{tabular}

Similarly, Table 4 illustrates that the main population characteristics of the two groups were comparable.

Table 4: Final survey-basic population profile

\begin{tabular}{|c|c|c|c|}
\hline Age & Mean age & Minimum & Maximum \\
\hline Control Group & 17 years & 9 years & 40 years \\
\hline Intervention Group & 17 years & 9 years & 39 years \\
\hline Years at Tsangaya school & Mean & Minimum & Maximum \\
\hline Control Group & 5 years & 1 year & 25 years \\
\hline Intervention Group & 5 years & 1 year & 25 years \\
\hline Family Profile & Average number of siblings & Father alive & Mother housewife \\
\hline Control Group & 7.8 & $86 \%$ & $87 \%$ \\
\hline Intervention Group & 7.5 & $85 \%$ & $89 \%$ \\
\hline Begging Profile & Beg every day & $\begin{array}{l}\text { Mean daily begging } \\
\text { hours }\end{array}$ & $\begin{array}{l}\text { Do small errands for } \\
\text { income }\end{array}$ \\
\hline Control Group & $30 \%$ & 2.4 Hours & $53 \%$ \\
\hline Intervention Group & $28 \%$ & 2.4 Hours & $53 \%$ \\
\hline Sleeping Option & Sleep with malam & Sleep at home & Other options \\
\hline Control Group & $48 \%$ & $12 \%$ & $37 \%$ \\
\hline Intervention Group & $54 \%$ & $19 \%$ & $24 \%$ \\
\hline Parents' Location & Live in the same community & $\begin{array}{l}\text { Live in another } \\
\text { community }\end{array}$ & \\
\hline Control Group & $61 \%$ & $39 \%$ & \\
\hline Intervention Group & $69 \%$ & $31 \%$ & \\
\hline
\end{tabular}




\begin{tabular}{|l|l|l|l|}
\hline Feeding Options & Beg for meal & Malam provides & Parents provide \\
\hline Control Group & $33 \%$ & $37 \%$ & $21 \%$ \\
\hline Intervention Group & $55 \%$ & $17 \%$ & Not enough to eat \\
\hline Food Intake & & Enough to eat & $25 \%$ \\
\hline Control Group & $75 \%$ & $47 \%$ \\
\hline Intervention Group & $52 \%$ & & \\
\hline
\end{tabular}

\section{Conclusions}

By drawing on a close study of a skills-training intervention in a very poor community which had expressed a high demand for such an intervention, this article hopes to have raised three important concerns about the neglect of skills training within international development agendas.

First, the choice between primary education and skills development is not so clear in the eyes of the poor communities as it is in the planning documents of the development agencies. Committed to EFA targets, donors prioritise primary education, while the poor communities concerned with basic survival often express an explicit preference for investment in skills development to improve young people's immediate incomegeneration potential. How should development agencies respond when faced with such competing agendas in the field? This issue needs further deliberation.

Second, by mapping details of a non-formal skills-training model which adapted the standard features of non-formal primary school—a model today widely supported by all major development agencies (USAID 2012; UNICEF, 2014)—this article has tried 
to illustrate that the failure to prioritise skills development within international development agendas has led to a lack of experimentation and innovation in community-based skills-development models. Further, as has been argued by those critiquing the TVET toolkit approach (McGrath 2010, 2012), developing skills-training programmes that empower the poor requires a focus on the needs of the deprived populations and the kinds of training that they can access and utilise, rather than narrowly focusing on the needs of big businesses. Such an approach will also allow for more innovation in the design and delivery of skills-training programmes at the community level.

There is potential for large-scale community-based skills-development models to be developed and implemented through state agencies, rather than confining such models to unsustainable NGO-led pilots (ILO, 2011). Recruiting trainers from within the community, basing training at the trainers’ workshops or community-provided spaces, and involving the community in monitoring projects can yield more relevant and lowcost training than technical educational programmes taught in formal technical training institutes. Further, given the competitive environment where trainers often see their trainees as future rivals, these skill-training programmes should also prepare the youth to cope with competition; teaching about product diversification strategies could potentially yield high dividends. In a context where transition from primary to secondary education remains a serious challenge due to institutionalised challenges faced in ensuring access and quality, which are continuing to prove extremely difficult to overcome, skills-training agendas need to be integrated more actively into education programmes than most donor agencies today care to admit. 
Finally, the article has also shown that a well-developed micro-credit programme should be part of any skills-training programme when dealing with very poor communities; without access to start-up capital, the skills acquired cannot unlock entrepreneurial potential. Against growing claims that aspirations can improve actual life outcomes (Ray, 2003; Bernard et al., 2014; Serneels and Dercon, 2014), the evidence presented in this article suggests that such conclusions might have to be qualified when applied to very poor communities. When the actual resource constraints are extremely severe, and the level of an individual's social networks is restricted to the immediate community, improvement in aspirations on its own might not lead to improved outcomes. 


\section{Technical Annex}

\section{Variables influencing the probability of training completion}

Using the survey implemented with the youth who took part in the programme, an attempt was made to test particular variables highlighted in the survey (age, trainer quality, type of education, income, etc.) that could potentially affect the probability of a child completing the training programme. The following set of analyses attempt to identify the reasons why youth in the treatment group who received training may have failed to complete the programme. Using 'completion of the training programme' as the binary outcome variable, this analysis compares results from probit, logit, and LPM models. Findings do not differ greatly between models. The following tables display all three models.

\section{Section 1}

Table 1: Dependent variable - completion of training programme

Probit Logit LPM

\begin{tabular}{|c|c|c|c|c|c|c|}
\hline & (1) & (2) & (3) & (4) & (5) & (6) \\
\hline & C & $M$ & C & $M$ & C & $M$ \\
\hline \multirow[t]{2}{*}{ gov_prim_school } & 0.03 & 0.01 & 0.15 & 0.02 & 0.04 & 0.04 \\
\hline & $(0.20)$ & $(0.05)$ & $(0.35)$ & $(0.05)$ & $(0.06)$ & $(0.06)$ \\
\hline \multirow[t]{2}{*}{ islamiyya_school } & $-0.61 * * *$ & $-0.14 * * *$ & $-1.10 * * *$ & $-0.15^{* * *}$ & $-0.17 * * *$ & $-0.17 * * *$ \\
\hline & $(0.16)$ & $(0.04)$ & $(0.28)$ & $(0.04)$ & $(0.05)$ & $(0.05)$ \\
\hline tsangaya_school & $-0.46 * *$ & $-0.11 * *$ & $-0.80 *$ & $-0.11^{*}$ & $-0.09 *$ & $-0.09 *$ \\
\hline
\end{tabular}




\begin{tabular}{|c|c|c|c|c|c|c|}
\hline & $(0.23)$ & $(0.06)$ & $(0.42)$ & $(0.06)$ & $(0.05)$ & $(0.05)$ \\
\hline \multirow[t]{2}{*}{ esspin_school } & 0.15 & 0.04 & 0.34 & 0.05 & 0.05 & 0.05 \\
\hline & $(0.18)$ & $(0.04)$ & $(0.33)$ & $(0.04)$ & $(0.04)$ & $(0.04)$ \\
\hline \multirow[t]{2}{*}{ Age } & $0.25 * *$ & $0.06 * *$ & $0.42 * *$ & $0.06 * *$ & $0.06 * *$ & $0.06^{* *}$ \\
\hline & $(0.10)$ & $(0.02)$ & $(0.17)$ & $(0.02)$ & $(0.03)$ & $(0.03)$ \\
\hline \multirow[t]{2}{*}{ age2 } & $-0.01 * *$ & $-0.00 * *$ & $-0.01 * *$ & $-0.00 * *$ & $-0.00 *$ & $-0.00 *$ \\
\hline & $(0.00)$ & $(0.00)$ & $(0.00)$ & $(0.00)$ & $(0.00)$ & $(0.00)$ \\
\hline \multirow[t]{2}{*}{ educ_level } & $0.23 * * *$ & $0.05 * * *$ & $0.39 * * *$ & $0.05^{* * *}$ & $0.05 * * *$ & $0.05 * * *$ \\
\hline & $(0.06)$ & $(0.01)$ & $(0.11)$ & $(0.01)$ & $(0.01)$ & $(0.01)$ \\
\hline \multirow[t]{2}{*}{ fam_inc_level } & -0.10 & -0.02 & -0.23 & -0.03 & -0.04 & -0.04 \\
\hline & $(0.13)$ & $(0.03)$ & $(0.23)$ & $(0.03)$ & $(0.03)$ & $(0.03)$ \\
\hline \multirow[t]{2}{*}{ enough_eat } & $0.35 * *$ & $0.08 * *$ & $0.57 * *$ & $0.08^{* *}$ & $0.07 *$ & $0.07^{*}$ \\
\hline & $(0.16)$ & $(0.04)$ & $(0.27)$ & $(0.04)$ & $(0.04)$ & $(0.04)$ \\
\hline \multirow[t]{2}{*}{ trainer_quality } & $0.36^{* *}$ & $0.08^{* *}$ & $0.67 * *$ & $0.09 * * *$ & $0.10^{* *}$ & $0.10^{* *}$ \\
\hline & $(0.15)$ & $(0.03)$ & $(0.27)$ & $(0.03)$ & $(0.04)$ & $(0.04)$ \\
\hline \multirow[t]{2}{*}{ stop_work_training } & 0.17 & 0.04 & 0.35 & 0.05 & 0.06 & 0.06 \\
\hline & $(0.19)$ & $(0.04)$ & $(0.34)$ & $(0.05)$ & $(0.04)$ & $(0.04)$ \\
\hline \multicolumn{5}{|l|}{ R-sq } & 0.180 & \\
\hline pseudo R-sq & \multicolumn{2}{|l|}{0.182} & \multicolumn{2}{|l|}{0.185} & & \\
\hline
\end{tabular}

Table 1 displays the results using the four variables of primary interest (Schools: Government Primary, Islamiyya, Tsangaya, and ESSPIN) as well as a number of controls which would probably have an impact on whether a child completes the training programme or not. The rationale behind these controls is presented below. 
Age and age2: Age could potentially have an impact on whether students complete the training or not. Younger students may be more determined than older students to learn new skills. However, age often does not share a linear relationship with most dependent variables, which is why we include age2 (the square of the age variable). In our regression model above, it is demonstrated that age shares a significant bell-curve relationship with completion rate, i.e. students are more likely to complete the training programme as age increases up to a certain cut-off age, after which point they are more likely to drop out.

Education level: Students with different levels of education may have different motivations for completing the training.

Family income level: It is possible that as family income increases, so should completion rate.

Enough to eat: Whether a child gets enough to eat or not is a reflection not only on income but also health.

Trainer quality: Higher trainer quality increases the likelihood of completing the programme. This result is also significant.

Stop work for training: This may alter the cost of continuing education. 
The $1^{\text {st }}, 3^{\text {rd }}$, and $5^{\text {th }}$ columns show the coefficient or parameter estimates of each of the models and are interpreted as 'the estimated effect of age on completion is 0.25 in the probit model', which is often a less clear way of showing the impact. The $2^{\text {nd }}, 4^{\text {th }}$, and $6^{\text {th }}$ columns display the marginal effects. The interpretation of these values is the average predicted difference in the probability of completing the training between individuals born one year apart. Therefore, the average difference in probability of completing the training programme is 6 per cent for each year. As can be seen, the different models do not vary greatly in values, signs, or significance.

\section{Section 2}

\section{Trainer quality}

In addition to the above analysis, it was also deemed fit to investigate if the quality of training, based on a number of characteristics, influence whether the almajiri students complete training courses. The survey had included a number of questions that highlight different characteristics that influence the quality of training. Table 1 notes trainer quality to have a significant impact on completion. This section therefore identifies the particular aspects of trainer quality that may have an impact on this relationship.

Where:

Questionnaire

\begin{tabular}{ll}
\hline trainer_bad_workshop & Had a bad workshop \\
trainer_encouraging & Was encouraging
\end{tabular}




\begin{tabular}{|c|c|}
\hline trainer_good_workshop & Had a good workshop \\
\hline trainer_knew_skills & Knew the skill techniques \\
\hline trainer_regular & Regular in holding the class \\
\hline trainer_scolded & Scolded a lot \\
\hline trainer_shared_skills & Shared the skills fully \\
\hline trainer_walking_dist & Located at a walkable distance \\
\hline
\end{tabular}

Note, Table 1.2 displays only the results of the trainer characteristics. All other variables from Table 1 are included in the models as controls but are not displayed in the table.

Table 1.2: Dependent variable - completion of training programme ${ }^{6}$

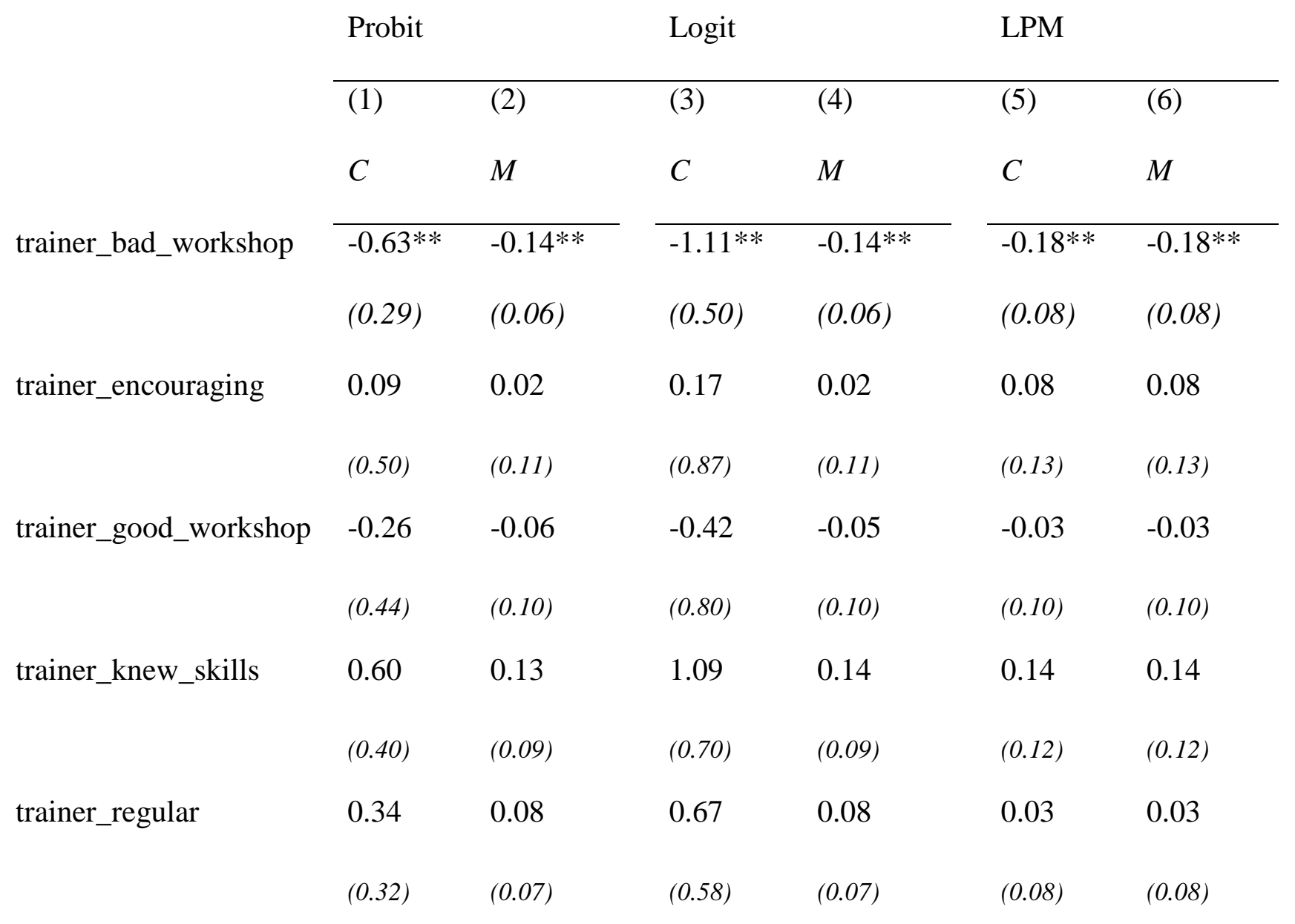




\begin{tabular}{|c|c|c|c|c|c|c|}
\hline \multirow[t]{2}{*}{ trainer_scolded } & $0.88 * * *$ & $0.20 * * *$ & $1.67 * * *$ & $0.21^{* * *}$ & $0.20 * * *$ & $0.20 * * *$ \\
\hline & $(0.27)$ & $(0.06)$ & $(0.53)$ & $(0.06)$ & $(0.05)$ & $(0.05)$ \\
\hline \multirow[t]{2}{*}{ trainer_shared_skills } & $1.09 * * *$ & $0.24 * * *$ & $2.15^{* * *}$ & $0.27 * * *$ & $0.22 * *$ & $0.22 * *$ \\
\hline & $(0.36)$ & $(0.08)$ & $(0.66)$ & $(0.08)$ & $(0.10)$ & $(0.10)$ \\
\hline \multirow[t]{2}{*}{ trainer_walking_dist } & 0.15 & 0.03 & 0.23 & 0.03 & 0.06 & 0.06 \\
\hline & $(0.22)$ & $(0.05)$ & $(0.39)$ & $(0.05)$ & $(0.05)$ & $(0.05)$ \\
\hline \multirow[t]{2}{*}{ stop_work_training } & 0.24 & 0.05 & 0.50 & 0.06 & 0.04 & 0.04 \\
\hline & $(0.23)$ & $(0.05)$ & $(0.42)$ & $(0.05)$ & $(0.05)$ & $(0.05)$ \\
\hline \multicolumn{4}{|l|}{ R-sq } & & \multicolumn{2}{|l|}{0.287} \\
\hline pseudo R-sq & \multicolumn{2}{|l|}{0.296} & \multicolumn{4}{|l|}{0.304} \\
\hline \multicolumn{7}{|c|}{ Standard errors in parentheses, where $C$ is the coefficient and $M$ represents the marginal effect } \\
\hline
\end{tabular}




\section{References}

Admassie, A. (2003) 'Child labour and schooling in the context of a subsistence rural economy: can they be compatible?', International Journal of Educational Development, 23: 167-185.

Allais, S. (2012a) ‘"Economic Imperialism", education policy and educational theory', Journal of Education Policy, 27(2): 253-74.

Allais, S. (2012b) 'Will skills save us? Rethinking the relationships between vocational education, skills development policies, and social policy in South Africa', International Journal of Educational Development, 32 (5): 632-42.

Amin, S., J. Ahmed, J. Saha, and E. F. Haque (2016) Delaying Child Marriage through Community-based Skill-development Programs for Girls, Dhaka: Population Council.

Antoninis, M. (2014) 'Tackling the largest global education challenge? Secular and religious education in northern Nigeria', World Development, 59: 82-92.

Bano, M. (2008) Engaged Yet Disengaged: Islamic Schools and the State in Kano, Nigeria, Religions and Development Research Programme Working Paper 29, Birmingham: University of Birmingham. 
Bernard, T., S. Dercon, K. Orkin, and S. Taffesse (2014) The Future in Mind: Aspirations and Forward-looking Behaviour in Rural Ethiopia, CSAE Working Paper, WPS/2014-2016.

Billetoft, J. (2014) Education and Skills Post-2015 and the Global Governance of Education: Agendas and Architecture, Network for International Policies and Cooperation in Education and Training, accessed 11 July 2017, http://www.norrag.org/de/publications/norrag-news/online-version/education-andskills-post-2015-and-the-global-governance-of-education-agendas-andarchitecture/detail/skills-and-employment-the-dfid-way.html

Brigaglia, A. (2008) '“We Ain’t Coming To Take People Away”: a Sufi praise-song and the representation of police forces in northern Nigeria', Annual Review of Islam in Africa, Issue No. 10, 2008-2009.

Conradie, I. (2013) 'Can deliberate efforts to realise aspirations increase capabilities? A South African case study', Oxford Development Studies, 41(2): 189-219.

Conradie, I. and I. Robeyns (2013) 'Aspirations and human development interventions', Journal of Human Development and Capabilities, 14(4): 559-80.

CUBE (2008) Islamiyya, Quranic, and Tsangaya Education in Kano, Kano: CUBE.

ESSPIN (2010) Integrating the Old with the New. Islamic Education Responds to the Demands of Modern Society, Kano: Education Sector Support Programme in Nigeria. 
ESSPIN (2015) Lessons from Tsangaya School Integration Model, Kano: Education Sector Support Programme in Nigeria.

European Commission (2012) TVET and Skills Development in EU Development Cooperation, Final Report No. No. 308055/1, http://ec.europa.eu/europeaid/sites/devco/files/tvet-study-aets-2012-finalreport_en.pdf

GMR and USI (2014) Progress in Getting All Children to School Stalls but Some Countries Show the Way Forward, Policy Paper 14, http://www.uis.unesco.org/Education/Documents/fs-28-out-of-school-children-en.pdf

Hoechner, H. (2011) 'Striving for knowledge and dignity: how Quranic students in Kano, Nigeria, learn to live with rejection and educational disadvantage', European Journal of Development Research, 23 (5): 712-28.

Hoechner, H. (2014) 'Traditional Qur'anic students (almajirai) in Nigeria: fair game for unfair accusations?', in M.-A. Pérouse de Montclos (ed.), Boko Haram: Islamism, Politics, Security and the State in Nigeria, Leiden: African Studies Centre.

Ibrahim, S. (2011) Poverty, Aspirations and Wellbeing: Afraid to Aspire and Unable to Reach a Better Life - Voices from Egypt, BWPI Working Paper 141, University of Manchester. 
ILO (2011) Skills Development through Community-based Rehabilitation (CBR): A Good Practice Guide, Switzerland: ILO,

http://www.ilo.org/wcmsp5/groups/public/@ed_emp/documents/publication/wcms_1 59136.pdf.

Jeffrey, C. (2010) Timepass: Youth, Class, and the Politics of Waiting in India, Stanford: Stanford University Press.

KERD (2014) Official Primary Transition Exam Results, Kano: Ministry of Education.

King, K., and R. Palmer (2007) Skills Development and Poverty Education: A State of the Art Review, NA: European Training Foundation.

McGrath, S. (2010) 'Beyond aid effectiveness: the development of the South African further and training college sector, 1994-2009', International Journal of Educational Development, 30 (5): 525-34.

McGrath, S. (2012) 'Vocational education and training for development: a policy in need of a theory?', International Journal of Educational Development, 32: 623-31.

Ministry of Education (MoE), Kano State (2008) Education Strategy Plan:2009_ 2018, Kano State: Federal Republic of Nigeria.

Ministry of Education (MoE) (2010) Kano State Annual Education Sector Report 2010, Kano State: Federal Republic of Nigeria. 
OECD (2012) Better Skills, Better Jobs, Better Lives - A Strategic Approach to Skills Policies, NA: OECD Publishing.

Palmer, R. (2014) 'Technical and vocational skills and post-2015: avoiding another vague skills goal?', International Journal of Educational Development, 39: 32-9.

Powell, L. (2012) 'Reimagining the purpose of VET - expanding the capability to aspire in South African future education and training students', International Journal of Educational Development, 32: 643-53.

Ray, D. (2003) Aspirations, Poverty and Economic Change, paper presented at World Bank conference on Culture and Development, Washington DC.

Rose, P. (2013) Are We on Track for a Global Education Goal? Reflections on Global Meeting on Education Post-2015, World Education Blog, accessed 14 July 2017, www.efare-port.wordppress.com.

Serneels, P. and S. Dercon (2014) Aspirations, Poverty and Education: Evidence from India, Young Lives Working Paper 125, Oxford: Oxford University.

UNESCO (2012) EFA Global Monitoring Report 2012. Youth and Skills: Putting Education to Work, Paris: UNESCO. 
UNICEF (2014) Community-based Schools Bring Hope to Afghanistan's Remote

Settlements, accessed 14 July 2017,

http://www.unicef.org/infobycountry/afghanistan_38434.html.

UNICEF (2015) Nigeria Country Profile, accessed 14 July 2017,

http://www.unicef.org/nigeria/children_1941.html.

USAID (2012) Meeting EFA: Afghanistan Community Schools, accessed 14 July

2017, http://pdf.usaid.gov/pdf_docs/PNADI076.pdf.

${ }^{1}$ The two EFA goals relating to skills development are (King and Palmer 2007):

Goal 3. Ensuring that the learning needs of all young people and adults are met through equitable access to appropriate learning and life skills programmes;

Goal 6. Improving all aspects of the quality of education and ensuring excellence of all so that recognised and measurable learning outcomes are achieved by all, especially in literacy, numeracy and essential life skills.

${ }^{2}$ A non-formal community schooling model as viewed in international development has come to stand for a one-room school focused on multi-grade teaching using childcentred teaching methods with a teacher recruited and trained from within the community.

${ }^{3}$ The ages of students at Tsangaya schools can range from 3 years old to those in their early to mid-twenties, although ideally most should have finished their core Quranic education by 15-17 years of age. Thus, the Tsangaya population consists of both children and young adults.

${ }^{4}$ Reported by Kano Ministry of Education in a 2016 interview.

${ }^{5}$ Verified during the fieldwork carried out in 2016.

${ }^{6}$ The following variables were included in the models, but excluded in the table: complete_esspin gov_prim_school islamiyya_school tsangaya_school esspin_school age age2 educ_level fam_inc_level enough_eat stop_work_training 